\title{
Transformasi Manajemen Fasilitas Pendidikan Pada Era Disrupsi Teknologi
}

\author{
Galih Abdi Nugraha ${ }^{\left.1^{*}\right)}$, Baidii), Syamsul Bakri ${ }^{3)}$ \\ 1,2,3Program Doktor Manajemen Pendidikan Islam, IAIN Surakarta \\ *Email korespondensi: galihabdin@gmail.com
}

\begin{abstract}
This study aims to determine the transformation of educational facility management in the era of technological disruption, where the place of this research was carried out at Duta Bangsa University, Surakarta. The methodology in this study uses a qualitative approach. Data collection techniques in this study are by observation, interviews and documentation. The method used to check the validity of the data is the triangulation method, namely by utilizing various methods as a consideration. The data analysis technique in this study is data that has been obtained by descriptive (non-statistical) method. Activities in data analysis, namely data reduction (data reduction), data display (data presentation), and verification (drawing conclusions). The results show that the transformation of educational facility management in the era of technological disruption that has been carried out by Duta Bangsa University Surakarta continues to be carried out starting from educational services that are directed towards technology-based both physical and non-physical in supporting universities, as well as in the implementation of all technology-based learning as a demands for technological developments that are happening more rapidly (disruption) in order to create a superior campus in the era of technological disruption.
\end{abstract}

Keywords: management transformation, educational facilities, technology disruption

\begin{abstract}
Abstrak
Penelitian ini bertujuan untuk mengetahui transformasi manajemen fasilitas pendidikan pada era disrupsi teknologi, dimana tempat penelitian ini dilakukan di Universitas Duta Bangsa Surakarta. Metodologi dalam penelitian ini menggunakan pendekatan kualitatif. Teknik pengumpulan data pada penelitian ini yaitu dengan observasi, wawancara dan dokumentasi. Metode yang digunakan untuk memeriksa keabsahan data adalah dengan triangulasi method yaitu dengan memanfaatkan berbagai metode sebagai pertimbangan. Teknik Analisis data pada penelitian ini yaitu data yang sudah diperoleh dengan cara deskriptif (non statistik). Aktivitas dalam analisis data, yaitu data reduction (reduksi data), data display (penyajian data), dan verification (penarikan kesimpulan). Hasil penelitian menunjukkan bahwa transformasi manajemen fasilitas pendidikan pada era disrupsi teknologi yang telah dilakukan oleh Universitas Duta Bangsa Surakarta terus dilakukan mulai dari layanan pendidikan yang diarahkan berbasis teknologi baik fisik maupun non fisik dalam menunjang perguruan tinggi, demikian pula dalam hal pelaksanaan pembelajaran semua berbasis teknologi sebagai tuntutan adanya perkembangan teknologi yang terjadi semakin cepat (disrupsi) demi mewujudkan kampus yang unggul pada era disrupsi teknologi.
\end{abstract}

Kata kunci: transformasi manajemen, fasilitas pendidikan, disrupsi teknologi

Saran sitasi: Nugroho, G. A., Baidi., \& Bakri, S. (2021). Transformasi Manajemen Fasilitas Pendidikan Pada Era Disrupsi Teknologi. Jurnal Ilmiah Ekonomi Islam, 7(02), 860-868. doi: http://dx.doi.org/10.29040/jiei.v7i2.2621

DOI: http://dx.doi.org/10.29040/jiei.v7i2.2621

\section{PENDAHULUAN}

Pendidikan merupakan ladang investasi terbesar dalam membangun dan membentuk manusia seutuhnya (insanulkamil). Sentuhan pendidikan di yakini mampu membentuk sumber daya manusia (human resources) yang beradab dan berkualitas.
Oleh karena itu, lembaga pendidikan hendaknya perlu mendapatkan sentuhan manajemen yang baik dan profesional, sehingga mampu survive dan berdaya saing. Para manajer dan unsur pendidikan lainnya dituntut mencari dan menerapkan suatu strategi manajemen baru yang dapat mendorong perbaikan 


\section{Jurnal Ilmiah Ekonomi Islam, 7(02), 2021, 861}

mutu di lembaganya. Salah satu manajemen yang dapat digunakan dalam hal ini adalah manajemen fasilitas pendidikan.

Sebagai ujung tombak bagi kemajuan bangsa, maka pendidikan harus diarahkan sesuai dengan dinamika perkembangan dunia global yang modern atau bias menyesuaikan sesuai dengan tuntutan zaman hal itu perlu dilakukan untuk merespon dinamika kemajuan zaman yang begitu cepat. Suatu bangsa dituntut untuk merpersiapkan pendidikan sebaik mungkin sehingga generasi penerusnya dapat diharapkan mampu menghadapi kemajuan perkembangan zaman. Dalam pendidikan ada istilah ilmu pendidikan (paedagogiek) dan pendidikan (paedagogie). Ilmu pendidikan lebih menitik beratkan kepada pemikiran perenungan tentang pendidikan. Pemikiran bagaimana baiknya sistem pendidikan, tujuan pendidikan, materi pendidikan, sarana dan prasarana pendidikan, cara penilaian, cara penerimaan siswa, guru yang bagaimana, jadi lebih menitik beratkan teori. Sedangkan pendidikan hal ini lebih menekankan dalam hal praktek, yaitu menyangkut kegiatan belajar mengajar, tetapi keduanya ini tidak dapat dipisahkan secara jelas. Keduanya harus dilaksanakan secara berdampingan, saling memperkuat peningkatan mutu dan tujuan pendidikan (Ahmadi \& Uhbiyati, 2015). Oleh sebab itu, pendidikan tidak hanya sebatas kegiatan belajar mengajar saja, banyak faktor dan penunjang lainnya yang diperlukan dalam proses pelaksanaannya terutama dalam upaya meningkatkan mutu pembelajaran.

Maju mundurnya suatu bangsa sangat bergantung pada penyelenggaraan pendidikannya, pendidikan yang baik dan bermutu maka baik dan bermutupulalah generasi penerusnya. Indonesia saat ini memiliki jumlah penduduk yang sangat tinggi, namun berbanding terbalik dengan kualitas pendidikannya yang masih rendah. hal ini menjadikan salah satu faktor semakin berkurangnya kepercayaan masyarakat terhadap pentingnya pendidikan, karena masyarakat menganggap berpendidikan atau tidak berpendidikan sama saja tidak bisa menjamin terpenuhinya kebutuhanmasyarakat.

Mutu dalam pendidikan memiliki karakteristik yang khas, karena pendidikan bukanlah industry. Dalam pendidikan, produk pendidikan itu bukanlah goods (barang) tetapi services (layanan). Pemakai (pelanggan) pendidikan ada yang bersifat internal dan eksternal. Guru dan siswa adalah pemakai jasa pendidikan yang bersifat internal. Sedangkan orang tua dan, masyarakat dan dunia kerja adalah pemakai eksternal jasa pendidikan. Pemakai ini perlu mendapat perhatian karena mutu dalam pendidikan harus memenuhi kebutuhan, harapan dan keinginan semua pemakai (stakeholders). Dalam hal ini pemakai yang menjadi fokus utama pendidikan adalah "learnears" (peserta didik). Peserta didik yang menjadi alasan utama diselenggarakannya pendidikan dan peserta didik pula yang menyebabkan keberadaan lembaga maupun sistem pendidikan (Nurdin, 2009).

Terkait dengan hal diatas, proses pembelajaran untuk menciptakan suasana yang kondusif, menyenangkan, efektif dan efisien tidak bisa terjadi begitu saja dalam suatu lembaga pendidikan. Pelaksanaan pembelajaran yang berkualitas ditentukan oleh suatu perencanaan yang baik dalam suatu manajemen. Oleh karena itu, dalam menentukan tujuan yang baik dalam suatu lembaga pendidikan supaya menciptakan pembelajaran yang berkualitas dibutuhkan pengelolaan manajemen yang baik.

Manajemen atau pengelolaan merupakan komponen integral dan tidak dapat dipisahkan dari proses pendidikan secara keseluruhan, tanpa manajemen tidak mungkin tujuan pendidikan dapat diwujudkan secara optimal, efektif dan efisien. Konsep tersebut berlaku disetiap lembaga pendidikan atau institusi yang memerlukan manajemen yang efektif dan efisien. Maksud efektif dan efisien adalah berhasil guna dan berdaya guna. Artinya, bahwa manajemen yang berhasil mencapai tujuan dengan penghematan tenaga, waktu dan biaya. Begitu pula dengan proses pendidikan yang baik memerlukan sarana dan prasarana atau fasilitas yang memadai, baik secara langsung maupun tidak langsung.

Pembicaraan mengenai sarana dan prasarana pendidikan dalam dunia pendidikan di Indonesia sendiri selalu bersamaan dengan upaya perbaikan mutu pendidikan itu sendiri. Karenanya dalam pasal 45 ayat (1) Undang-Undang Sisdiknas Tahun 2003 dijelaskan: "setiap satuan pendidikan formal dan non formal menyediakan sarana dan prasarana yang memenuhi keperluan pendidikan sesuai dengan pertumbuhan dan perkembangan potensi fisik, kecerdasan intelektual, sosial, emosional, kejiwaan peserta didik".

Pendidikan Tinggi adalah jenjang pendidikan setelah pendidikan menengah yang mencakup program diploma, program sarjana, program magister, program doktor, dan program profesi, serta program 


\section{Jurnal Ilmiah Ekonomi Islam, 7(02), 2021, 862}

spesialis, yang diselenggarakan oleh perguruan tinggi berdasarkan kebudayaan bangsa Indonesia (UndangUndang Nomor 12 Tahun 2012 Tentang Pendidikan Tinggi, 2012). Salah satu unsur pendukung penyelenggaraan pendidikan tinggi oleh perguruan tinggi adalah adanya fasilitas Pendidikan yang baik. Manajemen fasilitas pendidikan, merupakan alat atau media yang mempunyai peranan penting dalam penyelenggaraan pendidikan. Saat ini dunia telah mengalami perubahan yang begitu cepat, dunia telah memasuki era digital dan perubahan didalam dunia pendidikan khususnya dalam bidang fasilitas pendidikan, perguruan tinggi dinilai salah satu komponen sumber daya dengan investasi terbesar dan strategis dalam mendukung pengembangan ilmu pengetahuan dan teknologi, serta peningkatan mutu. Sebagai faktor yang mendukung atau support terhadap penyelenggaraan pendidikan pada perguruan tinggi, fasilitas pendidikan pendidikan perlu dikelola secara baik.

Dampak adanya pandemi Covid-19 memang sangat berpengaruh dalam berbagai aspek. Tidak lain halnya dengan pendidikan baik dalam jenjang PAUD hingga perguruan tinggi. Semua harus berjalan dengan sistem baru yang asing bagi sebagian murid bahkan orang tua (Suparya, 2020). Menyesuaikan diri dengan keadaan, berdamai dengan situasi adalah cara efektif agar bias berjalan seperti semestinya. Gangguan jaringan internet, hingga keterbatasan pengetahuan mengenai teknologi informasi menjadikan belajar dirumah menjadi hal yang menyulitkan. Tak jarang siswa hingga mahasiswa merasa tidak efektifnya belajar secara daring ini. Mereka terus menunggu dengan harap-harap cemas agar pandemic segera berakhir dan mereka bias belajar secara tatap langsung seperti sebelumnya. Sudah beberapa bulan semenjak diberlakukannya aturan untuk berlajar dirumah bagi semua jenjang pendidikan. Rasa bosan dan jenuh sudah banyak dirasakan, hingga rasa malas untuk belajar pun sudah mulai berdampak. Hal ini memicu kekhawatiran bagi sebagian orang tua mengenai bagaimana nasib anak mereka jika pandemi ini belum segera berakhir.

Manajemen fasilitas pendidikan seyogyanya menjadi perhatian utama dari setiap pengelola pendidikan. Dengan fasilitas pendidikan yang baik sesuai dengan jenjang dan program studi pada perguruan tinggi merupakan factor pendorong terhadap tercapainya tujuan Pendidikan. Sarana dan prasarana sangat mendukung dan memperlancar proses pendidikan. Sarana dan prasarana merupakan syarat mutlak bagi suatu lembaga pendidikan. Sarana dan prasarana pendidikan merupakan bagian yang tidak dapat terpisahkan dari proses pendidikan. Dengan demikian, untuk mencapai tujuan pendidikan, maka keberadaan sarana dan prasarana pendidikan tidak dapat diabaikan, melainkan harus dipikirkan untuk meningkatkan kualitas dan kuantitasnya di suatu lembaga pendidikan. Apalagi di era teknologi ini, dimana setiap lembaga pendidikan dihadapkan pada kemampuan menghadirkan sarana dan prasarana yang update, sesuai tuntutan zaman (Farikhah, 2015); (Kurniawati., \& Sayuti, 2013).

Saat ini pandemi menjadi tantangan dalam mengembangkan kreativitas terhadap penggunaan teknologi, bukan hanya transmisi pengetahuan, tapi juga bagaimana memastikan pembelajaran tetap tersampaikan dengan baik. Pembelajaran daring menjadi tantangan bagi dunia pendidikan dengan situasi Indonesia yang memiliki ribuan pulau. Bagaimana teknologi dapat digunakan, bagaimana penyediaan akses internet pada daerah-daerah terpencil dimana barang elektronik tanpa akses internet pun masih menjadi suatu kemewahan. Ini merupakan tantangan bagi semua pihak, saat ini kita harus bekerja keras bersama bagaimana membawa teknologi menjawab permasalahan nyata yang terjadi pada mahasiswa dan pelajar yang kurang beruntung dalam hal ekonomi maupun teknologi yang berada di daerah-daerah terpencil.

Dengan memperhatikan dinamika perubahan dunia saat ini manajemen fasilitas pendidikan dituntut mampu meresponnya. Revolusi industri 4.0. ditandai dengan perkembangan teknologi yang radikal atau disrupsi. Hadirnya revolusi industri 4.0 perlu direspons secara kelembagaan melalui rekonstruksi sistem pembelajaran yang inovatif, kurikulum yang mengintegrasikan pendidikan dengan system kerja digital, misalnya, dengan information technology (IT), operational technology (OT), internet of things (IoT), dan big data analitic. Saat ini pandemi Covid-19 menjadi pendorong semakin dan pesatnyanya era disrupsi ini berkembang. Pandemi Covid-19 telah memberikan gambaran atas kelangsungan dunia pendidikan di masa depan melalui bantuan teknologi. Berangkat dari kenyataan saat ini dunia tengah mengalami disrupsi teknologi, demikian halnya dengan perguruan tinggi mempunyai tanggungjawab untuk melakukan transformasi manajemen fasilitas pendidikannya. 


\section{Jurnal Ilmiah Ekonomi Islam, 7(02), 2021, 863}

Universitas Duta Bangsa Surakarta merupakan perguruan tinggi yang memiliki visi menjadi universitas unggul di bidang bisnis dan kewirausahaan di tingkat global 2038. Semangat terhadap visi yang telah ditetapkan tersebut, persaingan perguruan tinggi yang semakin ketat di era teknologi saat ini, serta adanya pandemi Covid-19 ini yang belum tahu kapan akan berakhir menjadikan Universitas Duta Bangsa Surakarta senantiasa melakukan transformasi manajemen fasilitas pendidikannya secara terus menerus demi tercapainya universitas yang unggul di era disrupsi. Layanan pendidikan di Universitas Duta Bangsa Surakarta juga mengalami perubahan dalam fasilitas pendidikan untuk memenuhi kebutuhan yang saat ini telah mengalami perkembangan dalam hal teknologi (disrupsi), mulai dari proses sosialisasi penerimaan mahasiswa baru dan melakukan transformasi berbagai fasilitas pendidikan yang lainnya.

Berdasarkan uraian latar belakang di atas, bahwa peneliti memiliki ketertarikan terhadap perubahan yang dilakukan oleh Universitas Duta Bangsa Surakarta dalam mengelola fasilitas pendidikan pada era disrupsi teknologi.

\section{KAJIAN TEORI}

2.1. Transformasi Manajemen Fasilitas Pendidikan Istilah transformasi lebih merujuk pada realitas proses perubahandalam Kamus Besar Bahasa Indonesia (KBBI), transformasi berarti perubahan bisa berupa bentuk, sifat, fungsi dan sebagainya. Dewi (2012) mengungkapkan bahwa Transformasi merupakan proses perubahan yang memiliki ciri-ciri antara lain:

a. Adanya perbedaan merupakan aspek yang paling penting di dalam prosestransformasi.

b. Adanya konsep ciri atau identitas yang menjadi acuan perbedaan di dalam suatu proses transformasi. Kalau dikatakan suatu itu berbeda atau dengan kata lain telah terjadi proses transformasi, maka harus jelas perbedaan dari hal apa, misal : ciri sosial apa, konsep tertentu yang seperti apa (meliputi : pemikiran, ekonomi atau gagasan lainnya) atau ciri penerapan dari sesuatukonsep.

c. Bersifat historis, proses transformasi selalu menggambarkan adanya perbedaan kondisi secara historis (kondisi yang berbeda di waktu yang berbeda).

Secara etimologi berdasarkan Tim Pusat Bahasa Departemen Pendidikan Nasional pada Kamus Besar Bahasa Indonesia tahun 2003 seperti dikutip oleh
Samsudin bahwa transformasi adalah ebagai perubahan struktur gramatikal menjadi struktur gramatikal lainnya dengan menambah, mengurangi atau menata kembali unsur-unsurnya. Oleh karenanya, transformasi Pendidikan Islam adalah rekonstruksi terhadap perubahan sistem pendidikan Islam mulai dari paradigma masyarakat Islam masuk pada bagian internal sistem kelembagaan pendidikan Islam.

Transformasi dalam bahasa Inggris adalah transform yang berarti merubah bentuk atau rupa, Transformation yang berarti perubahan bentuk atau penjelmaan (Najoan \& Mandey, 2011). Transformasi dan inovasi manajemen pendidikan dapat diartikan sebuah perubahan total dan menyeluruh serta mencakup segala aspek sampai menjadi sesuatu yang baru dalam usaha mengadakan perubahan dengan tujuan untuk memperoleh hal yang lebih baik di bidang manajemen pendidikan Islam..

Dari beberapa definisi tentang transformasi tersebut di atas disimpulkan bahwa transformasi adalah sebuah perubahan bentuk dengan perencanaan matang dan dilaksanakan secara taat azaz (konsisten) melalui proses perubahan berangsur-angsur dipengaruhi oleh unsur eksternal dan internal sampai pada tahap ultimate, dengan tujuan untuk memperoleh hal yang lebih baik.

Proses transformasi merupakan perubahan yang terjadi secara perlahan-lahan atau sedikit demi sedikit, tidak dapat diduga kapan dimulainya dan sampai kapan proses itu akan berakhir tergantung dari faktor yang mempengaruhinya, komprehensif dan berkesinambungan dan perubahan yang terjadi mempunyai keterkaitan erat dengan emosional (sistem nilai) yang ada dalam masyarakat.dari faktor internal seperti pola pikir masyarakat maupun faktor eksternal seperti lingkungan. Dengan demikian, masyarakat yang sudah mengalami pola pikir yang berbeda, maka cara memandang suatu hal juga akan berbeda pula.

Manajemen secara etimologi berasal dari bahasa Inggris yaitu dari kata kerja to manage yang artinya mengurus, mengatur, melaksanakan dan mengelola (Echols \& Shadily, 2019). Manajemen secara bahasa berarti bagaimana proses mengurus, mengatur, melaksanakan dan mengelola kegiatan-kegiatan dalam sebuah instansi atau organisasi untuk mencapai tujuan. Manajemen adalah ilmu dan seni mengatur proses pemanfaatan sumber daya manusia dan sumber-sumber lainnya secara efektif dan efisien untuk mencapai suatu tujuan tertentu (Hasibuan, 


\section{Jurnal Ilmiah Ekonomi Islam, 7(02), 2021, 864}

2007). Manajemen merupakan suatu kegiatan untuk mengurus, mengatur, melaksanaan dan mengelola suatu program sebuah lembaga sehingga dapat berjalan dengan efektif dan efisien sesuai dengan tujuan.

Menurut Siagian (2012) manajemen secara terminologi mempunyai definisi kemampuan dan keterampilan untuk memperoleh suatu hasil dalam rangka pencapaian tujuan melalui kegiatan-kegiatan orang lain. Manajemen ialah seni menyelesaikan pekerjaan melalui orang lain. Sedangkan menurut Hasibuan (2007) manajemen ialah seni menyelesaikan pekerjaan melalui orang lain. Ia juga mendefinisikan bahwa manajemen merupakan kegiatan mengelola orang-orang; pengambilan keputusan; dan proses mengorganisasi dan memakai sumber-sumber untuk menyelesaikan tujuan yang sudah ditentukan. Manajemen menurut M. Manulang (2005) ada tiga definisi yakni, manajemen adalah suatu proses, pelaksanaan suatu tujuan tertentu diselenggarakan dan diawasi.

Berdasarkan uraian tersebut di atas, dapat diketahui bahwa manajemen adalah proses merencanakan, mengorganisasikan, menggerakkan, mengawasi, dan mendayagunakan sumber daya organisasi dalam rangka untuk mencapai tujuan organisasi secara efektif dan efisien. Manajemen diselenggarakan dalam sebuah lembaga atau instansi agar segala kegiatan dapat berjalan secara efektif dan efisien sesuai tujuan lembaga.

Menurut Mulyono, membagi fungsi-fungsi manajemen itu atas empat fungsi yang lebih dikenal dengan istilah POAC, yaitu: planning (perencanaan); organizing (pengorganisasian); actuating (pelaksanaan); dan controlling (pengawasan) (Mulyono, 2008). Dalam kegiatan belajar mengajar sarana dan prasarana sangat diperlukan dalam rangka menunjang kelancaran proses kegiatannya, sehingga pengelolaan sarana dan prasarana sangat diperlukan oleh setiap instansi terutama sekolah. Sarana dan prasarana adalah segala sesuatu yang berupa barang, baik secara langsung maupun tidak langsung mendukung pelaksanaan proses belajar-mengajar. Sarana dan prasarana menjadi bagian penting dalam mendukung pembelajaran, karena tanpa adanya sarana dan prasarana yang mendukung, maka proses pembelajaran tidak dapat berjalan secara optimal, oleh karena itu pengelolaan sarana dan prasarana sangat diperlukan untuk mewujudkan pembelajaran yang efektif.
Dalam proses manajemen terlibat fungsi-fungsi pokok yang ditampilkan oleh seorang manajer/pemimpin, yaitu perencanaan (planning), pengorganisasian (organizing), pemimpinan (leading), dan pengawasan (controlling). Oleh karenaitu, manajemen diartikan sebagai proses merencana, mengorganisasi, memimpin dan mengendalikan upaya organisasi dengan segala aspeknya agar tujuan organisasi tercapai secara efektif dan efisien.

Sarana pendidikan adalah peralatan dan perlengkapan yang secara langsung dipergunakan dalam proses belajar mengajar, seperti gedung, ruang kelas, meja, kursi, serta media pengajaran. Adapun prasarana pendidikan adalah fasilitas yang secara tidak langsung menunjang jalannya proses pengajaran, seperti halaman, kebun, tamansekolah, dan jalan menuju sekolah (Qomar, 2007). Jika prasarana ini dimanfaatkan secara langsung untuk proses belajar mengajar seperti taman sekolah untuk mengajarkan biologi atau halaman sekolah menjadi lapangan olah raga, maka komponen tersebut berubah posisi menjadi sarana pendidikan. Ketika prasarana difungsikan sebagai sarana, berarti prasarana tersebut menjadi komponen dasar. Akan tetapi, jika prasarana berdiri sendiri atau terpisah, berarti posisinya menjadi penunjang terhadap sarana

Manajemen sarana dan prasarana adalah kegiatan yang mengatur untuk mempersiapkan segala peralatan/material bagi terselenggaranya proses pendidikan di sekolah. Manajemen sarana dan prasarana dibutuhkan untuk membantu kelancaran proses belajar mengajar (Rohiat, 2008). Manajemen sarana dan prasarana dapat diartikan sebagai kegiatan menata, mulai dari merencanakan kebutuhan, pengadaan, penyimpanan dan penyaluran, pendayagunaan, pemeliharaan, penginventarisan dan penghapusan serta penataan lahan, bangunan, perlengkapan, dan perabot sekolah serta tepat guna dan tepat sasaran (Sobri, 2009).

Fasilitas pendidikan dengan nama lain sarana dan prasarana memiliki pengertian yang terdefiniskan sebagai berikut: prasarana secara istilah adalah peralatan yang tidak langsung mempengaruhi tercapainya tujuan dalam pendidikan, misalnya: lokasi/tempat, bangunan insttitusi pendidikan tinggi, lapangan olahraga, dan sebagainya. Sedangkan sarana berarti alat langsung untuk mencapai tujuan pendidikan, misalnya: ruang, buku, perpustakaan, laboratorium, dan sebagainya (Solichin, 2011). 


\section{Jurnal Ilmiah Ekonomi Islam, 7(02), 2021, 865}

\subsection{Manajemen Fasilitas Pendidikan di Era Disrupsi}

Beberapa hal yang semula begitu sulit, begitu lama, begitu mahal dalam proses produksi mendadak jadi mudah, cepat, dan murah. Ingat, Ekonomi membicarakan macam-macam upaya manusia menghadapi kelangkaan. Revolusi industry menurunkan, malah terkadang menghilangkan beberapa kelangkaan tersebut, sehingga waktu, tenaga, dan uang yang semula digunakan untuk mengatasi kelangkaan-kelangkaan tersebut mendadak jadi bebas, jadi bias digunakan untuk hal lain, untuk mengatasi kelangkaan yang lain.

Semua revolusi itu terjadi menggunakan revolusi sebelumnya sebagai dasar. Industri 2.0 takkan muncul selama kita masih mengandalkan otot, angin, dan air untuk produksi. Industri 3.0 intinya meng-upgrade lini produksi dengan komputer dan robot. Jadi, industri 4.0 juga pasti menggunakan komputer dan robot ini sebagai dasarnya. Kemajuan apa saja yang muncul di dunia computer kita akhir-akhir ini: Pertama, kemajuan yang paling terasa adalah internet. Semua computer tersambung kesebuah jaringan bersama. Komputer juga semakin kecil sehingga bias menjadi sebesar kepalan tangan kita, makanya kita jadi punya smartphone. Bukan Cuma kita tersambung kejaringan raksasa, kita jadinya selalu tersambung kejaringan raksasa tersebut. Inilah bagian pertama dari revolusi industry keempat: "Internet of Things" saat komputerkomputer yang ada di pabrik itu tersambung ke internet, saat setiap masalah yang ada di lini produksi bias langsung diketahui saat itu juga oleh pemilik pabrik, dimanapun si pemilik berada. Ponsel pintar (smartphones) yang senantiasa membuat kita terhubung dengan dunia luar adalah instrument penting dalam revolusi industri 4.0. Kedua, kemajuan teknologi juga menciptakan 1001 sensor baru, dan 1001 cara untuk memanfaatkan informasi yang didapat dari sensor-sensor tersebut yang merekam segalanya selama 24 jam sehari. Informasi ini bahkan menyangkut kinerja pegawai manusianya. Misalnya, kini perusahaan bias melacak gerakan semua dan setiap pegawainya selama berada di dalam pabrik. Dari gerakan tersebut, bias terlihat, misalnya, kalau pegawai-pegawai tersebut menghabiskan waktu terlalu banyak di satu bagian, sehingga bagian tersebut perlu diperbaiki. Masih ada 1001 informasi lainnya yang bias didapat dari 1001 data yang berbeda, sehingga masih ada 1001-1001 cara meningkatkan produktivitas pabrik yang semula tak terpikirkan. Karena begitu banyaknya ragam maupun jumlah data baru ini, aspek ini sering disebut Big Data. Ketiga, berhubungan dengan yang pertama dan kedua, adalah Cloud Computing. Perhitungan-perhitungan rumit tetap memerlukan computer canggih yang besar, tapi karena sudah terhubung dengan internet, karena ada banyak data yang bias dikirim melalui internet, semua perhitungan tersebut bias dilakukan di tempat lain, bukannya di pabrik. Jadi, sebuah perusahaan yang punya 5 pabrik di 5 negara berbeda tinggal membeli sebuah super computer untuk mengolah data yang diperlukan secara bersamaan untuk kelima pabriknya. Tidak perlu lagi membeli 5 super computer untuk melakukannya secara terpisah. Keempat, ini yang sebetulnya paling besar: Machine learning, yaitu mesin yang memiliki kemampuan untuk belajar, yang bisa sadar bahwa dirinya melakukan kesalahan sehingga melakukan koreksi yang tepat untuk memperbaiki hasil berikutnya. Ini bias dilukiskan dengan cerita "Alpha Zero AI". Sebelum Machine Learning, sebuah computer melakukan tugasnya dengan diperintahkan atau diinstruksikan oleh manusia.

Dengan segala potensi yang ada kita harus menjadi pelaku aktif yang mendapat manfaat atas perubahan besar itu. Tantangan kedepan adalah meningkatkan skill tenaga kerja di Indonesia, mengingat $70 \%$ angkatan kerja adalah lulusan SMP. Pendidikan sekolah vokasi menjadi suatu keharusan agar tenaga kerja bias langsung terserap keindustri. Kesimpulannya revolusi industri 4.0 bukanlah suatu kejadian yang menakutkan, justru peluang makin luas terbuka bagi anak bangsa untuk berkontribusi terhadap perekonomian nasional. Dengan adanya revolusi industri 4.0 mengubah arah pandang dunia menjadi semakin maju secara teknologi dan kompetisi menjadi semakin ketat. Oleh karena itu sebagai perguruan tinggi harus bias mengikuti perkembangan zaman dengan meningkatkan kualitas pelayanan khususnya di bidang sarana dan prasarana sebagai usaha untuk menciptakan kegiatan belajar mengajar yang lebih baik sehingga mampu menciptakan produk yang berkualitas sesuai dengan tuntutan zaman.

Berbicara mengenai disrupsi tentunya tidak dapat dipisahkan dari dampak revolusi industri 4.0. Clayton M. Christensen Professor dari Harvad Bussines School (HBS) seperti dikutip oleh Ohoitimur (2018) menjelaskan pandangannya tentang disrupsi. Bahwa disrupsi berarti inovasi yang menguntungkan, bukan karena suatu perusahaan memiliki highly regulated procedures, melainkan karena suatu penyangkalan 


\section{Jurnal Ilmiah Ekonomi Islam, 7(02), 2021, 866}

(deception) atau pengabaian terhadap apa yang dianggap remeh. Kecenderungan perusahaan dalam industri yang besar dan sukses adalah memiliki sistem yang tertata dengan prosedur kerja yang menjamin kualitas produk, dengan tujuan menciptakan produk dengan kualitas terbaik guna memenuhi permintaan dan kebutuhan para konsumennya. Inovasi dalam organisasi dan proses produksi yang berorientasi pada menjaga kualitas produk atau mengembangkan produk dengan mutu untuk memuaskan konsumen. Demikian halnya dengan inovasi teknologi diadopsi dalam rangka mempertahankan kualitas produk dan permintaan pasar.

Sedangkan menurut Rhenald Kasali, perguruan tinggi akan menjadi sasaran disrupsi untuk merespon tuntutan global dan dunia digital. Dimasa yang aka dating akan ada entrant yang mendisrupsi diri, lalu memimpin perubahan mendasar. Gelombang disruptif dalam pendidikan meliputi (Kasali, 2017): 1). "On demand" jasa-jasa pendidikan dan ketrampilan, termasuk perkuliahan, ujian. 2). “Open source”jasajasa pendidikan dan ketrampilan. 3). Aplikasi-aplikasi pendidikan yang mobile dan responsif . 4). Kurikulum yang bersifat personal dan "tailor made". 5). Layanan konten tanpa batas. 6). Platform pendidikan kolaboratif. 7). Kursus-kursus dan materi-materi gratis secara online.

Mindset disrupsiakan membawa tantangan dalam manajemen pendidikan tinggi kearah yang lebih baik dengan ide menjadi smart campus. Smart campus atau kampus pintar merupakan konsep pengintegrasian infrastruktur yang sudah ada dengan Information Communication Technology (ICT). Smart Campus memberikan kelebihan dalam mempermudah proses pembelajaran (e-learning), demikian halnya terhadap layanan-layanan administrasi yang dilakukan oleh tenaga kependidikan dengan memanfaatkan teknologi informasi yang berbasis aplikasi (Priatna, 2019). Tantangan dan peluang manajemen pendidikan dalam menghadapi era disrupsi yang berbasis pada smart campus perlu diantisipasi dengan melakukan perencanaan yang tepat untuk bertransfromasi dalam menyongsong kecepatan kemajuan teknologi. Peremajaan sarana prasarana, riset, dan inovasi juga perlu dilakukan untuk menopang kualitas pendidikan, riset, dan inovasi (Priatna, 2019).

\section{METODOLOGI PENELITIAN}

Penelitian ini menggunakan pendekatan kualitatif. Pendekatan penelitian kualitatif ini, untuk melakukan penelitian yang berkaitan dengan transformasi manajemen fasilitas pendidikan pada era disrupsi teknologi. Jenis penelitian yaitu deskriptif kualitatif. Pada hakikatnya penelitian deskriptif kualitatif adalah suatu metode dalam meneliti status sekelompok manusia, suatu objek dengan tujuan membuat deskriptif, gambaran atau lukisan secara sistematis, faktual dan akurat mengenai fakta-fakta atau fenomena yang diselidiki (Convello G. Cevila, 2003). Peneliti mengambil setting penelitian di Universitas Duta Bangsa Surakarta. Sebagai Perguruan Tinggi Swasta yang memiliki perkembangan fasilitas Pendidikan atau sarana prasarana penunjang pendidikan yang cukup baik serta konsen terhadap pemenuhan kebutuhan sarana dan prasarana sebagai upaya peningkatan mutu pendidikan.

Teknik pengumpulan data pada penelitian ini yaitu dengan observasi, wawancara dan dokumentasi. Metode yang digunakan untuk memeriksa keabsahan data adalah dengan triangulasi method yaitu dengan memanfaatkan berbagai metode sebagai pertimbangan. Triangulasi ini dilakukan dengan jalan membandingkan dan mengecek informasi atau data yang diperoleh dari dokumentasi dengan hasil pengamatan dan interview (Moleong, 2014). Triangulasi ini dilakukan dengan; (1) membandingkan data hasil pengamatan dengan data hasil wawancara, (2) membandingkan apa yang dikatakan orang di depan umum dengan yang dikatakan pribadi, (3) membandingkan apa yang dikatakan orang tentang situasi penelitian dengan apa yang didapat selama penelitian, (4) membandingkan keadaan dan perspektif seseorang dengan berbagai pendapat dan pandangan yang lain, dan (5) membandingkan hasil wawancara dengan isi suatu dokumen yang berkaitan.

Teknik Analisis data pada penelitian ini yaitu data yang sudah diperoleh dengan cara deskriptif (non statistik), yaitu penelitian yang dilakukan dengan menggambarkan data yang diperoleh dengan kata kata atau kalimat yang dipisahkan untuk kategori untuk memperoleh kesimpulan. Yang bermaksud mengetahui keadaan sesuatu mengenai apa dan bagaimana, berapa banyak, sejauh mana, dan sebagainya. Adapun analisis data kualitatif dalam penelitian ini adalah analisis interaktif dan berlangsung secara terus menerus sampai tuntas, sehingga datanya sudah jenuh. Aktivitas dalam analisis data, yaitu data reduction (reduksi data), data 


\section{Jurnal Ilmiah Ekonomi Islam, 7(02), 2021, 867}

display (penyajian data), dan verification (penarikan kesimpulan) (Moleong, 2011).

\section{HASIL PENELITIAN}

4.1. Layanan Pendidikan di Universitas Duta Bangsa Surakarta

Layanan pendidikan di Universitas Duta Bangsa Surakarta juga mengalami perubahan dalam fasilitas pendidikan untuk memenuhi kebutuhan yang saat ini telah mengalami perkembangan dalam hal teknologi (disrupsi). Mulai dari proses sosialisasi kepada masyarakat yang dahulu dilakukan secara langsung tatap muka kesekolah-sekolah, kantor dinas, kelurahan sekarang dilakukan melalui virtual, pembayaran SPP yang biasanya dilakukan dengan tunai dengan petugas sekarang bisa transfer dan langsung terhubung dengan data keuangan, registrasi dan heregistrasi yang dulu mengisi form secara manual sekarang sudah online dengan aplikasi, ujian penerimaan mahasiswa baru biasanya dilaksanakan setiap gelombang yang dilakukan dengan mahasiswa megerjakan soal-soal secara langsung dan diselenggarakan dikampus dan pegumuman di buat serentak berbeda dengan sekarang pelayanannya menggunakan one day service, sekarang calon mahasiswa baru setelah melakukan pendaftaran tanpa harus datang kekampus dilakukan secara online kemudian calon mahasiswa baru bias langsung melakukan ujian penerimaan mahasiswa baru berbasis android di hari itu juga dan langsung bisa melihat hasil ujian. Kemudian kegiatan perkuliahan, biasanya dosen memberikan modul atau buku pegangan, sekarang Universitas Duta Bangsa Surakarta memberikan layanan e-Book dan layanan itu gratis, mahasiswa bisa menggunakannya dengan cara mengunduh di laman yang telah disediakan oleh pihak kampus. Pembangunan-pembangunan fisik gedung seperti, laboratorium, penambahan ruang kelas, lapangan olahraga, hotel dan juga asrama mahasiswa, klinik juga terus dilakukan dalam rangka memberikan pelayanan yang maksimal serta mewujudkan kampus yang memiliki fasilitas yang lengkap dan nyaman dalam rangka mendukung kelancaran kegiatan pembelajaran.

\subsection{Pelaksanaan Pembelajaran di Universitas Duta} Bangsa Surakarta

Pelaksanaan Pembelajaran di Universitas Duta Bangsa Surakarta sebelum terjadinya pandemi Covid19 sudah menggunakan sistem teknologi berupa e- learning, hanya saja saat itu belum sepenuhnya menggunakan e-learning (semi online). Terjadinya pandemi ini menjadikan pelaksanaan pembelajaran di Universitas Duta Bangsa Surakarta sepenuhnya online, termasuk beberapa kegiatan-kegiatan akademik lainnya seperti seminar dilakukan secara online, pelaksanaan pembimbingan terhadap mahasiswa baik mahasiswa semester berjalan maupun terhadap mahasiswa semester akhir juga dilakukan secara online. Bagi Universitas Duta Bangsa Surakarta dengan background teknologi dan kesehatan, kejadian pandemi Covid-19 tidaklah membuat pelaksanaan pembelajaran berubah total, sebab pemakaian teknologi pembelajaran sudah diterapkan jauh-jauh hari sebelum pandemi ini terjadi. Namun dengan adanya pandemi ini tentunya menjadikan Universitas Duta Bangsa Surakarta semakin baik lagi dalam mempersiapan pelaksanaan pembelajaran jarak jauh (online) dengan melakukan transformasi sarana dan prasarana yang berkaitan dengan pelaksanaan pembelajaran secara online tersebut. Mulai dari penambahan bandwidth data internet secara signifikan agar proses pembelajaran online dapat lancar dengan tidak adanya kendala pada sambungan internet, peremajaan komputer dan perangkatnya sebagai pendukung proses pembelajaran online dan peremajaan terhadap fasilitas pembelajaran yang lainnya.

\section{KESIMPULAN}

Berdasarkan latar belakang dan hasil penelitian di atas, maka dapat disimpulkan bahwa transformasi manajemen fasilitas pendidikan pada era disrupsi teknologi yang telah dilakukan oleh Universitas Duta Bangsa Surakarta terus dilakukan mulai dari layanan pendidikan yang diarahkan berbasis teknologi baik fisik maupun non fisik dalam menunjang perguruan tinggi, demikian pula dalam hal pelaksanaan pembelajaran semua berbasis teknologi sebagai tuntutan adanya perkembangan teknologi yang terjadi semakin cepat (disrupsi) demi mewujudkan kampus yang unggul pada era disrupsi teknologi.

\section{DAFTAR PUSTAKA}

Ahmadi, A. \& Uhbiyati, N. (2015). Ilmu Pendidikan. Jakarta: Rineka Cipta

Convello G. Cevila, d. (2003). Pengantar Metode Penelitian. Jakarta: Universitas Indonesia.

Dewi, E. (2012). Transformasi Sosial dan Nilai Agama. Substantia: Jurnal Ilmu-Ilmu Ushuluddin, 14(1), 112-121. 
Echols, J. M., \& Shadily, H. (2019). Kamus inggris indonesia.

Farikhah, S. (2015). Manajemen lembaga pendidikan.

Hasibuan, M. S. (2007). Manajemen Dasar, Pengertian dan Masalah. Jakarta: Bumi Aksara.

Indonesia, P. R. (2012). Undang-Undang Nomor 12 Tahun 2012 tentang Pendidikan Tinggi. Jakarta (ID): Sekretariat Negara.

Kasali, R. (2017). Disruption (11th ed.). Gramedia Pustaka Utama.

Kurniawati, P. I., \& Sayuti, S. A. (2013). Manajemen Sarana dan Prasarana di SMK N 1 Kasihan Bantul. Jurnal Akuntabilitas Manajemen Pendidikan, 1(1), 98-108.

Manullang, M. (2005). Manajemen Sumber Daya Manusia. Yogyakarta: BPFE

Moleong, L. J. (2011). Metodologi Penelitian Kualitatif, cetakan XXIX. Bandung: PT. Remaja, Rosdakarya.

Mulyono. (2008). Manajemen Administrasi dan Organisasi Pendidikan . Yogyakarta: Ar-Ruzz Media.

Nayoan, S. J., \& Mandey, J. C. (2011). Transformasi sebagai Strategi Desain. Media Matrasain, 8(2).

Nurdin, N. (2009). Quality Assurance in Higher Education. Jurnal Administrasi Pendidikan, 10(2).
Ohoitimur, J. (2018). Disrupsi:Tantangan bagi Perkembangan Ilmu Pengetahuan dan Peluang bagi Lembaga Pendidikan Tinggi. Respons, 23(02), 143-166.

Priatna, T. (2019). Disrupsi Pengembangan Sumber Daya Manusia Dunia Pendidikan di Era Revolusi Industri 4.0. In Zahir Publishing. Pusat Penelitian dan Penerbitan UIN Sunan Gunung Djati Bandung.

Qomar, M. (2007). Manajemen Pendidikan Islam . Malang : Erlangga.

Rohiat. (2008). Manajeen Sekolah-Teori Dasar dan Praktik dilengkapi dengan Contoh Rencana Strategis dan Rencana Operasional. Bandung: PT. Refika Aditama .

Siagian, S. P. (2012). Manajemen Sumber Daya Manusia. Jakarta: Bumi Aksara.

Sobri. (2009). Pengelolaan Pendidikan . Yogyakarta: Multi Pressindo.

Solichin, M. M. (2011). Manajemen Sarana-Prasarana Pendidikan. Nuansa Vol.8 No.2, 159.

Suparya, I. K. Belajar dari Rumah Selama Masa Pendemi Covid 19. COVID-19: Perspektif Pendidikan, 63. 